\title{
The Effect of Teachers' Role in Learning on the Learning Outcomes of High School Students
}

\author{
Khairil Hadi $^{1}$, Dazrullisa ${ }^{2}$, Endang Susantini ${ }^{3}$, Sunu Kuntjoro ${ }^{4}$ \\ ${ }^{I}$ Department of Biology education, STKIP Bina Bangsa Meulaboh, Aceh, Indonesia \\ ${ }^{2}$ Department of Mathematics education, STKIP Bina Bangsa Meulaboh, Aceh, Indonesia \\ ${ }^{3}$ Department of Biology education, Universitas Negeri Surabaya, Indonesia \\ ${ }^{4}$ Science Education Study Program, Universitas Negeri Surabaya, Indonesia \\ herilbio@yahoo.co.id,dazrullisa@yahoo.co.id,endangsusantini@unesa.ac.id,sunukuntjoro@unesa.ac.id
}

\begin{abstract}
The teacher influences the success of the learning process. Therefore, teachers need to have the ability and carry out the learning process as a learning agent as mandated by Law No. 14 of 2005. This study aims to determine the effect of the Role of the teacher as a learning agent on the learning interest of high school students. This research was conducted in SMA Negeri Aceh Barat and Nagan Rayadas, totaling 20 schools. The research sample in this study was 400 high school classes $X$ students. Sampling was done using random sampling. The instrument used in this study consisted of a teacher questionnaire as a learning agent and a student interest questionnaire. Data analysis techniques used a simple regression test in order to determine the effect of the teacher's role as a learning agent on student learning interest. Before the simple regression test was carried out, the researcher carried out the prerequisite test, namely the data normality test and the data homogeneity test. The results showed that (1) The Role of the teacher as a learning agent was in good criteria with an average percentage of $70.8 \%$., (2) Student interest in learning was in good criteria with an average percentage of $72.8 \%$., and (3) The effect of the teacher's Role as a learning agent on student interest in learning is $20 \%$.
\end{abstract}

Keywords

the role of teachers, learning agents, student interest in learning, biology

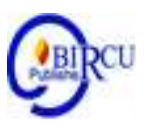

\section{Introduction}

The implementation of the teaching and learning process takes place if there is an interaction between students and teachers. Teachers are at the forefront of the formal education system that affects student learning success. Because the existence of the Role of the teacher is a very significant factor (Hamdayana, 2016). The success of the learning process carried out by the teacher if there is a change in students in the form of affective, cognitive, and psychomotor (Hadi, K et al . 2019). So because of that, teachers must always hone skills in accordance with the times. Musfah (2011) states that teachers must have competencies in accordance with national education standards, so that they can carry out their duties and roles properly and successfully.

Law No. 14 of 2005 explains that the position of teachers as professionals serves to increase the dignity and Role of teachers as agents of learning. The learning agent in question is the Role of the teacher as a facilitator, motivator, trigger, instructor of learning, and giver of learning inspiration for students. Al-Naqa \& Abu-Ward (2012) stated that everyone expects teachers to perform all these roles to achieve the educational goals 
sought in classrooms based on the philosophy of society. However, it cannot be denied that there are still teachers who have not been able to carry out their roles in accordance with Law No. 45 of 2005 as teachers as learning agents. The improvement in educational quality strongly emphasizes the importance of the role of the school as an of the school as the role of the principal in developing education. (Musdiani, 2019).

The results of preliminary observations made by researchers identified that there are still teachers who have not been able to adjust the teaching and learning process in the classroom as learning agents. For example, there are still teachers who cannot use technology, lack of feedback from the teacher, minimal variation in the use of learning models, low integrity in giving student grades, teachers have not been able to position themselves as partners, and student learning motivation is low. Manizar, E (2015) states that at school there are often children who like to play truant, do not pay attention, sleep, and play with friends when the learning process takes place. This shows that the teacher has not succeeded in providing the right motivation to encourage students to learn with all their might and mind . If this problem continues to emerge in the education system, it cannot be denied that the achievements of the next generation of the nation will be left behind with other countries. Therefore, it is appropriate that a teacher needs to hone his / her abilities from various reference sources in accordance with those mandated by the Law of the Republic of Indonesia.

The teacher's Role is to help and encourage students to develop several skills, as well as being a "source of information, advice, and knowledge ( Jones, L. (2007). According to Hayon, V, A et al. (2014) this method also requires maximum manifestation. the Role of the teacher as a learning agent in order to enable students to learn to achieve optimal achievement and learning outcomes. Learning achievement can be achieved if an interest in learning arises in students. Learning interest is the first thing that must be affirmed by teachers to students. Learning interest is the desire to learn something which was taught by the teacher diligently and seriously The results of interviews with several biology teachers at the high school where the researchers showed that students' interest in learning was still low This was reflected in the attitudes of students who were still in and out of the classroom during learning hours.

Previous research has proven that teachers play a key role in bringing about successful change in education (Heijden et all , 2014). One of the external factors that affect student achievement is the influence of the teacher's Role (Yusuf \& Dada, 2016). Some of the most prominent outcomes of the challenges of modern and future education are those related to the Role of teachers in the educational process (Haries, Mojies, 2007). Regarding the Role of teachers as learning agents, Atkinson (2000) reported that the level of teacher motivation plays an important role in student learning. The same thing was also expressed by Tosun and Taskesenligil (2011) that student learning achievement increased because of motivation and strategy in the learning process. Sinaga (2020) states that teaching is one of the tasks of a teacher that must be carried out well because in teaching assignments the teacher conveys and transforms his knowledge to students.

To achieve the goals of national education, learning in schools must be implemented effectively (Hartini, et al., 2018). In order to improve the quality of the learning process and outcomes, many ways and efforts can be made by educators in realizing educational instructional goals, one of which is the use of learning materials or learning materials (Ediyani, 2020). The achievement of the learning process according to educational goals is largely determined by how the learning process is carried out by the teacher to students. This success will have an impact on students who are marked by changes in behavior both in terms 
of cognitive, affective, and knowledge. So therefore, teachers who are considered to have the ability to transfer knowledge to students are expected to be able to carry out tasks professionally as learning agents according to their disciplines. Because of this, this research needs to be done in order to determine the quality and quantity of teachers as agents of learning in influencing student interest in learning.

\section{Research Methods}

\subsection{Research Approach, Type, and Design}

This study uses a quantitative research approach because in this research hypothesis testing is carried out. While the type of research used is ex post facto research (causal research). According to Sugiyono (2015) a causal relationship is a relationship that is causal in nature. So because of that, the research design used is as shown below.

\subsection{Research Place and Sample}

This research was conducted in two districts in Aceh province, namely West Aceh and Nagan Raya districts. This study focuses on high school (SMA) class X MIA . The sample in this study were students from 20 schools as the research sample with a total of 200 students. . The sampling technique used random sampling technique.

\subsection{Research Instruments}

In this study, the instrument used was a questionnaire sheet consisting of a questionnaire on the Role of the teacher as a learning agent and a questionnaire on learning interests. The questionnaire sheet is used to determine the quality of the teacher's Role as a learning agent and the interest in learning questionnaire aims to determine student interest in learning. The questionnaire assessment used a linkert scale with a range of 1 to 5 .

\subsection{Data Analysis Technique}

The data analysis in this study was carried out using SPSS software which consists of descriptive statistical tests and inferential statistics. Descriptive statistics are used to determine the mean value of the questionnaire answers. While the inferential test is used to test the relationship between the teacher's role and student learning outcomes using simple regression analysis.

\section{Result and Discussion}

\subsection{Result}

\section{a. Descriptive Data of Teacher Roles and Student Interest in Learning}

The results of distributing questionnaires to 400 hundred high school students from two districts regarding the quality of teachers as learning agents and the influence of student interest in learning are outlined in table 1 and table 2.

Table 1. Descriptive Quality of Teachers as Learning Agents

\begin{tabular}{|c|c|c|c|c|c|c|c|}
\hline \multirow{3}{*}{ No. } & $\begin{array}{c}\text { Origin High } \\
\text { School }\end{array}$ & \multicolumn{4}{|c|}{ Teacher indicators as learning agents / } & \multirow{2}{*}{$\begin{array}{c}\sum \\
\text { Average Value 1\% }\end{array}$} \\
\cline { 3 - 7 } & & Facilitator & Motivator & Booster & $\begin{array}{c}\text { Learning } \\
\text { Engineer }\end{array}$ & $\begin{array}{c}\text { Giver of } \\
\text { Inspiration }\end{array}$ & $\begin{array}{c}\text { Average } \\
\text { Value /\% }\end{array}$ \\
\hline \multirow{2}{*}{1} & West Aceh & 3.53 & 3.72 & 3.53 & 3.5 & $\begin{array}{c}3.42 \\
(68.4 \%)\end{array}$ & $\begin{array}{c}3.54 \\
(70.8 \%)\end{array}$ \\
\hline
\end{tabular}




\begin{tabular}{|l|l|c|c|c|c|c|c|}
\hline & School & & & & & & \\
\hline 2 & Nagan & 3.54 & 3.8 & 3.52 & 3.41 & 3.4 & 3.53 \\
& Raya High & $(70.8 \%)$ & $(76 \%)$ & $(70.4 \%)$ & $(68.2 \%)$ & $(68 \%)$ & $(70.6 \%)$ \\
& School & & & & & \\
\hline $\begin{array}{c}\text { Average Value } \\
\text { /\% }\end{array}$ & 3.54 & 3.76 & 3.53 & 3.46 & 3.41 & 3.54 \\
$(70.8 \%)$ & $(75.2 \%)$ & $(70.6 \%)$ & $(69,2 \%)$ & $(68.2 \%)$ & $(70.8 \%)$ \\
\hline
\end{tabular}

From the table above, it is known that the teacher's average score as a learning agent is in good criteria with a value of $70.8 \%$. The table above also shows that of the five predefined indicators, it shows that good criteria consist of facilitator indicators $(70.8 \%)$, motivators $(75.2 \%)$, and promoters $(70.6 \%)$. Meanwhile, the indicators of learning engineers and inspirers were in quite good criteria with $69 \%$ and $68.2 \%$ respectively.

Table 2. Descriptive Student Interest in Learning

\begin{tabular}{|c|c|c|c|c|c|c|c|}
\hline \multirow[t]{2}{*}{ No. } & \multirow{2}{*}{$\begin{array}{l}\text { Origin } \\
\text { High } \\
\text { School }\end{array}$} & \multicolumn{5}{|c|}{$\begin{array}{c}\text { Teacher indicators as learning agents / } \\
\text { Average value/\% }\end{array}$} & \multirow{2}{*}{$\begin{array}{l}\sum \text { Average } \\
\text { Value } 1 \%\end{array}$} \\
\hline & & Facilitator & Motivator & Booster & $\begin{array}{l}\text { Learning } \\
\text { Engineer }\end{array}$ & $\begin{array}{l}\text { Giver of } \\
\text { Inspiration }\end{array}$ & \\
\hline 1 & $\begin{array}{l}\text { West } \\
\text { Aceh } \\
\text { District } \\
\text { High } \\
\text { School }\end{array}$ & $\begin{array}{c}3,7 \\
(73.9 \%)\end{array}$ & $\begin{array}{c}3.86 \\
(77.11 \%)\end{array}$ & $\begin{array}{c}3.62 \\
(72.32 \%)\end{array}$ & $\begin{array}{c}3.48 \\
(69.52 \%)\end{array}$ & $\begin{array}{c}3.57 \\
71.39 \%)\end{array}$ & $\begin{array}{c}3.65 \\
(70.8 \%)\end{array}$ \\
\hline 2 & $\begin{array}{l}\text { Nagan } \\
\text { Raya } \\
\text { High } \\
\text { School }\end{array}$ & $\begin{array}{c}3.63 \\
(72.68 \%)\end{array}$ & $\begin{array}{c}3,83 \\
(76.64 \%)\end{array}$ & $\begin{array}{c}3,6 \\
(71,899 \%)\end{array}$ & $\begin{array}{c}3,56 \\
(71.12 \%)\end{array}$ & $\begin{array}{c}3,53 \\
(70.64 \%)\end{array}$ & $3.63(70.6 \%)$ \\
\hline \multicolumn{2}{|c|}{$\begin{array}{l}\sum \text { Average } \\
\text { Value } 1 \%\end{array}$} & $\begin{array}{c}3.67 \\
(73.4 \%)\end{array}$ & $\begin{array}{c}3.85 \\
(77 \%) \\
\end{array}$ & $\begin{array}{c}3.61 \\
(72.2 \%) \\
\end{array}$ & $\begin{array}{c}3.52 \\
(70.4 \%) \\
\end{array}$ & $\begin{array}{c}3.55 \\
(71 \%)\end{array}$ & $\begin{array}{c}3,64 \\
(72.8 \%) \\
\end{array}$ \\
\hline
\end{tabular}

Table 2 shows that student interest in learning is influenced the highest by the Role of the teacher as a learning agent on the motivation indicator with a percentage of $77 \%$ (good), then followed by the facilitator indicator with a percentage of $73.4 \%$ (good), the trigger indicator with a percentage of $72.2 \%$ (good), inspirational indicators $(71 \%)$, and educational engineering indicators with a percentage of $70.4 \%$ (good). Meanwhile, the average value of students' interest in learning was $72,8 \%$ with good criteria.

\section{b. Data Normality and Homogeneity Test}

Test for normality and homogeneity of questionnaire data on the Role of the teacher as a learning agent.

Table 3. Tests of Normality

\begin{tabular}{|l|r|r|r|}
\hline & \multicolumn{3}{|c|}{ Kolmogorov-Smirnov $^{\text {a }}$} \\
\cline { 2 - 4 } & Statistics & \multicolumn{1}{c|}{ df } & \multicolumn{1}{c|}{ Sig. } \\
\hline SMA_Kab_Aceh_Barat & .072 & 200 & .013 \\
SMA_Kab_Nagan_Raya & .072 & 200 & .014 \\
\hline
\end{tabular}

a. Lilliefors Significance Correction 
The above table shows that both the data the teacher's role as an agent of learning from two high school districts of Aceh Barat and Nagan Raya normal distribution, where each Sig $(0,013)>0.05$ and $\operatorname{Sig}(0,014)>0.05$.

Table 4. Test of Homogeneity of Variances

Teacher_Role

\begin{tabular}{|c|c|c|c|}
\hline Levene Statistics & df1 & df 2 & Sig. \\
\hline .385 & 1 & 398 & .535 \\
\hline
\end{tabular}

The table above shows that the data on the Role of the teacher as a homogeneous learning agent, where $\operatorname{Sig}(0.535)>0.05$.

1. Test for Normality and Homogeneity of Data on Student Interest in Learning

Table 5. Tests of Normality

\begin{tabular}{|l|r|r|r|}
\hline & \multicolumn{3}{|c|}{ Kolmogorov-Smirnov $^{\text {a }}$} \\
\cline { 2 - 4 } & Statistics & \multicolumn{1}{c|}{ df } & \multicolumn{1}{c|}{ Sig. } \\
\hline SMA_Kab_Aceh_Barat & .075 & 200 & .009 \\
SMA_Kab_Nagan_Raya & .075 & 200 & .008 \\
\hline
\end{tabular}

a. Lilliefors Significance Correction

The table above shows that the two data on student interest in learning from two SMA districts of West Aceh and Nagan Raya are normally distributed, where Sig (0.009)>0.05 and Sig $(0.08)>0.05$, respectively.

Table 6. Test of Homogeneity of Variances

The Interests of Student Learr Learning

\begin{tabular}{|c|c|c|c|}
\hline Levene Statistics & df1 & df 2 & Sig. \\
\hline 6,711 & 1 & 398 & .010 \\
\hline
\end{tabular}

The table above shows that the results of the data on student interest in learning from the two districts came from homogeneous data, where Sig $(0.535)>0.05$.

\section{c. Simple Regression Test}

Table 7. The Value of the Regression Test the Effect of the Role of the Teacher as a

ANOVA

\section{Learning Agent on Interest in Learning}

\begin{tabular}{|ll|l|l|l|l|l|}
\hline \multicolumn{2}{|l|}{ Model } & $\begin{array}{l}\text { Sum } \\
\text { Squares }\end{array}$ & df & Mean Square & F & Sig. \\
\hline 1 & Regression & 10807,734 & 1 & 10807,734 & 99,685 & $.000^{\text {a }}$ \\
Residual & 43150,839 & 398 & 108,419 & & \\
& Total & 53958,572 & 399 & & & \\
\hline
\end{tabular}

a. Predictors: (Constant), The Role of Teachers as Learning Agents

b. Dependent Variable: Students' Learning Interest 
Table 8. Percentage of the Influence of the Teacher's Role as a Learning Agent on Student Interest in Learning

Model Summary

\begin{tabular}{|l|r|r|r|r|}
\hline Model & R & R Square & $\begin{array}{c}\text { Adjusted R } \\
\text { Square }\end{array}$ & $\begin{array}{l}\text { Std. Error of } \\
\text { the Estimate }\end{array}$ \\
\hline 1 & $.448^{\mathrm{a}}$ & .200 & .198 & 10,4125 \\
\hline
\end{tabular}

a. Predictors: (Constant), The Role of Teachers as

Learning Agents

From the table above (table 7) it is known that the $\mathrm{F}$ value counted at 99.685 with a significant level of $0.000<0.05$, it can be concluded that the Role of the teacher as a learning agent has an effect on student interest in learning. Table 8 shows that the magnitude of the relationship ( $R$ ) is 0.448 and it is obtained ( $R$ Square) of 0.200, which means that the influence of the teacher's Role as a learning agent on student learning interest is $20 \%$ and $80 \%$ is influenced by other factors .

\subsection{Discussion}

Interest is something that is done by feeling good about what is being done . Regarding the learning process, interest can be interpreted as feeling happy that students will study the material taught by the teacher diligently. A subject can only be studied if the student can focus on the subject, and the interest is one factor that enables concentration (GIE, T, L, 1985) .

From the results of data analysis it is known that students' interest in learning biology at school is in good criteria. But even so, it cannot be denied that the more teachers can carry out the learning process according to the Role of learning agents, the students' interest in learning will continue to increase. It is penny there with the phrase Slameto (2010) s emakin close the relationship is stronger or more powerful it is in the self interest.

\section{a. The Role of the Teacher as a Facilitator}

In this Role, in research schools that researchers do teachers position themselves as superiors, not colleagues on the grounds that students need to be respected. It needs to be straightened out that being respected by students does not have to position the teacher as a boss, but colleagues who work professionally. Sindunata (2001) states that in a partnership relationship, students and teachers are colleagues. Because the teacher cannot teach a competency if there are no students. The teacher as a facilitator is aware of actions to build groups, lead supervision and suggest innovations, and activities that develop skills and lifelong learning of the teacher (Ellerani, P \& Gentile, and M. 2013).

The Role of the facilitator is the Role of providing services to facilitate students in the learning activities / process (Sanjaya, 2012 ). The teacher will realize that as a facilitator, the teacher will use active learning methodologies, active classroom learning techniques, and project-based learning. The teacher will realize the Role of the facilitator, and the teacher will improve the quality of the facilitator as a teacher. The teacher will think from the point of view of the facilitator. Teachers will use new teaching strategies in the teaching and learning process 


\section{b. The Teacher's Role as a Motivator}

Motivation can arise from outside or from within the individual himself. Regarding the learning process, one of the motivations can arise due to the teacher. Motivation is an effort to increase activities in achieving a certain goal, including learning activities. The concept of motivation is felt every stage of life is very important to be handled in educational institutions whose input and output are human (Kaya et al. 2013). Individual motivation appears as an important subject that must be approached (Cem et al. 2018).

In schools where researchers conducted research, they identified that biology teachers in high school had motivated them in the form of punishment, praise, and assignments. However, the punishment given is still in negative aspects such as standing in front of the class. This does not have to be done continuously, because it can embarrass students of classmates. Praise is done in a verbal form which means that there has been no attempt to give gifts to students. Praise should be done in many variations, such as giving gifts and so on. In giving assignments, the teacher does so by giving questions in the form of descriptions and multiple choices to do at home. There is no task that directs students to make observations in the school environment.

Hayon, V, A et al (2014) stated that the Role of the teacher at this point is to provide encouragement to learn so that there is a high desire to learn intrinsically (Hayon, V, A et al, 2014). Shrivastava, L (2012) states that To encourage students to become self-motivated independent learners, teachers can do the following: - (a) Provide frequent initial positive feedback which supports the belief that they can do well. (b ) Ensure opportunities for student success by assigning assignments that are not too difficult or too easy. (c) Helping students to find personal meaning and value in teaching materials. (d) Create an open and positive atmosphere. (e) Help students feel that they are valued members of the learning community.

\section{c. The Role of the Teacher as a Driver}

The teacher's Role as a trigger is a role that can arouse feelings and desires from students to learn with confidence. Hayon, V, A et al (2014) states that teachers are enthusiasts or stimulants of students' appetite for learning. He must multiply the potential of students and develop it according to their aspirations and aspirations to achieve the goals of an activity, namely learning activities even for a future. Teachers spur students to achieve successful learning in school or through teacher learning spurs students to be able to achieve their life goals optimally (Mulyasa, 2009). Increasing the quality and scale of innovation in education will positively affect education itself and benefit the whole society (Serdyukov, P. 2016) .

In schools where researchers conducted research, biology teachers have not shown themselves to be good triggers. This is identified from students who are still afraid to meet with the teacher in solving problems related to the learning process. Another thing is also seen that the teacher is still unable to give assignments according to student competencies. We recommend that professional teachers be able to assign assignments according to student competency levels. The teacher as a driver also needs to do fun learning. The research school shows that the teacher has done fun learning, but the teacher does not reflect on the learning in determining the next learning process. So to make it easier for the teacher to act as a spur in the learning process, the teacher must position himself as a student relationship or partner. Laird (1983) states that the relationship that is built between teachers and students is a supporting relationship. 


\section{d. The Role of the Teacher as an Educational Engineer}

Teachers as educational engineers are intended to be creative. Because the learning engineer is one of the things that can affect the development of students' knowledge, affective, and psychomotor. Teachers as engineers cannot be separated from preparation, implementation, and evaluation. Because teachers as engineers cannot be separated from teaching methods and / or models, the use of technology, and reflection to improve the learning process that is carried out.

In high school as a sample in this study it shows that the biology teacher has implemented the learning process with a variety of learning models. But in practice, the teacher still has problems regarding the syntax or steps in using the learning model. Teachers at school that researchers do also have obstacles in terms of using technology in learning.

\section{e. The Teacher's Role as an Inspiration}

The teacher as an inspiration provider must be able to support the ability of students to solve problems and find ideas or ideas in learning about what material they are learning. Hayon, V, A et all (2014) stated that the G uru are strongly encouraged to provide inspiration to bring great ideas. Supporting the abilities of students can be done by providing real learning and using evaluations that have higher order thinking criteria. In schools where researchers conducted research, it was identified that biology teachers have not been able to carry out the Role of inspirer well. Because teachers still have weaknesses in formulating evaluation tools with higher order thinking criteria and teachers only use textbooks at school as a learning resource without any other additional references.

\section{Conclusion}

Based on the results and discussion, the conclusions in this study are:

1. The Role of the teacher as a learning agent is in good criteria with an average percentage of $70.8 \%$.

2. Student interest in learning is in good criteria with an average percentage of $72.8 \%$.

3. The effect of the teacher's Role as a learning agent on student interest in learning is $20 \%$.

\section{References}

Al-Naqa, S., Sheikh, I. (2012). Palestinian Teacher's Role in Promoting Social Reform and Development. Al-Aqsa Journal , 16 (1): 1-29.

Atkinson, ES 2000. An Investigation into the Relationship between Teacher Motivation and Pupil Motivation. Educ. Psychol . Vol. 20, 45-57.

Anzar, S. F., \& Mardhatillah, M. (2018). Analisis Kesulitan Belajar Siswa Pada Pembelajaran Bahasa Indonesia di Kelas V SD Negeri 20 Meulaboh Kabupaten Aceh Barat Tahun Ajaran 2015/2016. Bina Gogik: Jurnal Ilmiah Pendidikan Guru Sekolah Dasar, 4(1).

Cem, Senol and Mustafa Akdag. 2018. The Relation between Prospective Teachers' Attitudes towards Uncertainty and Motivation in Teaching. Educ. Sci., 8, 122; doi: 10.3390 / educsci8030122 (pp 1-11)

Ediyani, M., Anwar, K., Husaini, Zuhaimi, R., and Hidayat, T. (2020). The Analysis of Arabic Learning Materials in Al-'Arabiyah Baina Yadaik Book with the Principle of Material Development Approach. Budapest International Research and Critics InstituteJournal (BIRCI-Journal) Vol 3 (2): 965-974.

Ellerani, P \& x Gentile, M. 2013. The Role of teachers as facilitators to develop empowering leadership and school communities supported by the method of cooperative 
learning. Procedia - Social and Behavioral Sciences, pp 12 - 17. doi: 10.1016 / j.sbspro.2013.09.144

Febriyanti, Harum Dwi, Supri Wahyudi Utomo and Juli Murwani. 2014. The Effect of Using Support Books and Additional Hours of Study on Learning Outcomes at SMAN 1 Wungu, Madiun Regency. Assets: Journal of Accounting and Education Vol. 3 (2), 108-117.

Gie, T, L. 1985. Efficient Learning Method . Yokyakarta: Center for Study Progress. Hamdayama, J. (2016). Teaching Methodology. Jakarta: PT Bumi Aksara.

Hadi, K., Dazrullisa, D., Hasruddin, H \& Manurung, B. 2019. The Effect of Teaching Materials Based on Local Value Integrated by Character Education through PBL Models on Students' High Order Thinking Skill. Britain International of Humanities and Social Sciences (BIoHS) Journal . Vol. 1, No. 2, October 2019, Page: 213223. doi : http://doi.org/10.33258/biohs.v1i2.54

Hayon, V, A., Linfto, G., \& Gerardus, U. 2014. The Relationship between the Implementation of Teacher Professional Attributes and the Role of Teachers as Learning Agents with the Reduction of Learning Problems in Junior High School Accelerated Students in Kupang City. Journal of Education and Learning, Volume 21, Number 2, Pp 119-131

Harris, Mojis, 2007 - Harris, A., Mojis, D. (2007). Improving Schools through the Role of Teacher as Leader, Translation. Ola Reform, Nile Group Arab, Cairo.

Hartini, S. Firdausi, Misbah, nf Sulaeman. (2018). The Development of Physics Teaching Materials Based on Local Wisdom to Train Saraba Kawa Characters. Jpii 7 (2), pp 130- 137. doi: 10.15294 / jpii.v7i2.14249.

HRMA van der Heijden , JJM Geldens, D. Beijaard \& HL Popeijus. (2014). Characteristics of teachers as change agents. Journal of Teachers and Teaching, Volume 21, Issue 6, pp 681-699. https://doi.org/10.1080/13540602.2015.1044328

Kaya, F.s.S; Y1ld1z, B .; Y1ld1z, H. 2013. An Evaluation of the Motivation Levels of Primary School Teachers in Terms of Herzberg's two-factor Theory. Acad. Sigh. Int. Ref. Online J. 39, 1-18.

Laird, D. (1982). Approaches to Training and Development. Fifth Printing. Philippines: Addison-Wesley Publishing Company, Inc.

Mardhatillah, M., \& Trisdania, E. (2018). Pengembangan Media Pembelajaran Berbasis Macromedia Flash Untuk Meningkatkan Kemampuan Membaca Siswa di SD Kelas II Negeri Paya Peunaga Kecamatan Meureubo. Bina Gogik: Jurnal Ilmiah Pendidikan Guru Sekolah Dasar, 5(1).

Musdiani, Mardhatillah, and Khausar. (2019). Analysis the Role of Headmaster in Applying Quality of Education in Primary School Districts, Aceh Barat. Budapest International Research and Critics in Linguistics and Education (BirLE) Journal Vol 2 (3): 27-35.

Musfah, J. (2011). Improving Teacher Competence through Training and Learning Resources for Theory and Practice . Jakarta: Golden Manizar, E. 2015. The Role of Teachers as Motivators in Learning . tadrib vol. 1, No.2 pp. 171-188

Sari, P, P., Utomo, S, W., and Wiajaya, A, L. (2017). The Influence of the Role of Teachers and the School Environment on Student Motivation in Class Xi of Accounting at SMP N 5 Madiun. The 9th FIPA: Accounting Education Scientific Forum - Universitas PGRI Madiun, Vol. 5 No. 1, p. 381-398, e-ISSN: 2337-9723.

Sinaga, A. I., Jaya, F., and Hasibuan, A. P. (2020). The Teacher's Role in Applying the Hadith Release Method in SDIT Cendekia Pematangsiantar District. Budapest International Research and Critics in Linguistics and Education (BirLE) Journal Volume 3, No 3, August 2020, Page: 1577-1580. 
Sindhunata, (2001). Education: Anxiety throughout the Ages. Yogyakarta: Kanisius Publisher.

Shrivastava, L. (2012). Student's Motivation: A Teacher's Role. International Journal of Research and Development - A Management Review (IJRDMR). Volume-1, Issue - 1, pp 63-65.

Slameto. (2010). Learning and Affecting Factors. Jakarta: Renika Cipta

Sugiyono. (2015). Combination Research Methods (Mix Methods) . Bandung: Alfabeta

Serdyukov, P. 2016. Innovation in education: what works, what doesn't, and what to do about it? Journal of Research in Innovative Teaching \& Learning. Vol. 10 No. 1, pp. 433. DOI 10.1108 / JRIT-10-2016-0007.

Sanjaya, W. (2012). Planning and Design of Learning Systems. Jakarta: Kencana Prenada Media Gruop.

Tosun, C. \& Taskesenligil, Y. (2011). The effect of problem based learning on student motivation toward chemistry classes and on learning strategies. Journal of Turkish Science Education , 9 (1), pp 104-125.

Yusuf, HO, \& Dada, AA (2016). Infact of Teachers 'Qualification and Experience on the Performance of Students' in Colleges of Education in Kaduna State, Nigeria. The Online Journal of Quality in Higher Education, 3 (2), 52-61. Retrieved from http://www.tojqih.net/journals/tojqih/articles /v03i02/v03i02-05.pdf. 